\title{
Risk factors of metabolic syndrome among adult Sudanese sickle cell anemia patients
}

\author{
Awab Omer Babiker and Lamis AbdelGadir Kaddam *i()
}

\begin{abstract}
Background: Sickle cell disease is a hereditary disorder characterized by haematological anaemia. Several studies assumed that adult sickle patients might develop metabolic syndrome features as hyperglycaemia, hypertension and dyslipidaemia. The aim of this study was to evaluate the metabolic syndrome risk factors among adult Sudanese with sickle cell anemia in the steady state.

Methods: A prospective cross sectional study design was conducted among thirty adult patients with sickle cell anemia $\mathrm{Hb}$ SS (mean age $23 \pm 6.1$ years) and thirty healthy individuals matched for age and gender. Waist and hip circumferences were measured by simple tape. Venous blood sample were analysed to detect blood glucose level, uric acid, total cholesterol, triglycerides, low and high-density lipoprotein after $8 \mathrm{~h}$ overnight fasting by spectrophotometer. Blood pressure was measured by sphygmomanometer. National Cholesterol Education Program-Adult Treatment Panel III was utilised to define metabolic syndrome. Statistical analysis was performed SPSS software version 23. Continuous data were expressed using mean \pm SD. P-value of $<0.05$ (two-tailed) was used to establish statistical significance. Unpaired independent T- test was used.

Results: No significant difference in mean systolic blood pressure in patients group compared to control ( $P$ value $=0.3)$. Mean value of diastolic blood pressure was significantly low in patients group compared to control (65.4 \pm 10.4 VS72.33 $\pm 8.27 \mathrm{mmHg}, P$ value $<0.001)$. Fasting triglycerides level was comparable between patients group and control ( $P$ value $=$ 0.56). While high-density lipoprotein was significantly lower in sicklers compared to control $(30.2 \pm 8.2 \mathrm{mg} / \mathrm{dL}$ vs $44.71 \pm 1$. $85 \mathrm{mg} / \mathrm{dL}, P$ value $<0.001)$. Fasting blood glucose was significantly low in sickle compared to control $(92.6 \pm 13 \mathrm{mg} / \mathrm{dL}$ vs $106.83 \pm 25.11 \mathrm{mg} / \mathrm{dL} P$ value $<0.001)$. Uric acid level was not statistically differed in patients group compared to control ( $p$ value $=0.5$ )
\end{abstract}

Conclusion: There was significant decrease in fasting High-density lipoprotein, diastolic blood pressure, mean arterial pressure and fasting blood glucose among SCA patients compared to control. There was no significant difference in waist circumference, systolic blood pressure, fasting triglycerides and uric acid levels between patients and control groups.

Keywords: Metabolic syndrome, Hyperlipidaemia sickle cell anemia, Steady state

\section{Background}

Sickle cell anemia (SCA) is a genetic haematological disorder caused by mutations in the sixth amino acid to be substituted from glutamic acid to valine and characterized mainly by vaso-occlusion and anaemia [1]. Nowadays several researches investigate metabolic syndrome (MetS) development among SCD patients [2]. Little is known, however, about the prevalence of metabolic syndrome determinants among adults with SCD [2]. Metabolic

\footnotetext{
* Correspondence: lamiskaddam@hotmail.com

Department of Physiology, Faculty of Medicine, Alneelain University, P.O. Box: 11121, 12702 Khartoum, Sudan
}

syndrome is a cluster of conditions that are associated with a two-fold increase in cardiovascular disease outcomes and a 1.5-fold increase in mortality $[2,3]$. To diagnose the metabolic syndrome, patients must achieve three out of five factors: increased waist circumference, triglyceride levels, blood pressure and fasting blood glucose levels, and decreased HDL levels [2, 3].

Waist circumference was found to be lower in patients with SCD, although waist to hip ratio is greater than their matched control; which is most probably due to recurrent avascular necrosis of head of the femur that causes a decrease in hip circumference [4]. SCD is 
associated with hypocholestrolemia when compared to control group [1]. They found low level of low density lipoprotein cholesterol (LDL), low level of high density lipoprotein (HDL) and high triglycerides level [1]. Two latter parameters by their powerful atherogenic potential can possibly carry an early cardiovascular risk [1]. Recent study showed that patients with (SCD) may develop insulin resistance [5]. Insulin resistance might be due to high Reactive Oxygen Species (ROS) and decrease antioxidants or increase ferritin level [5]. Sickle cell disease has a great effect on blood pressure [6]. Patients have decreased diastolic blood pressure and increased pulse pressure, and the systolic blood pressure might be higher compared to control [6]. The significantly lower diastolic blood pressure and increased pulse pressure noted in patients could be as a result of the hyperdynamic circulation from chronic anaemia [6]. Although these differences were not observed when the effect of anaemia was eliminated by comparing patients and controls with mild anaemia [6]. Also sickle cell disease may be associated with hyperurecimia which could be due to increased catabolism of nucleic acid [7].

Sickle cell disease patients develop high reactive oxygen species due to higher autoxidation of HbS generating superoxide anion radicals and hence hydrogen peroxide, which it has great effects on serum blood glucose and lipid profile [5]. These will increase the rates of metabolic syndrome with its complications.

Sickle cell disease nowadays categorized as syndrome rather than a disease. It affects many organs and can be consider as a life threatening condition. According to National Cholesterol Education Program, we measured waist circumference, fasting blood glucose, fasting lipid profile and blood pressure as characteristics of metabolic syndrome.

\section{Subjects and methods}

\section{Study design}

This is a prospective observational descriptive cross sectional study design. It was conducted in adult haematological clinic Military hospital, Omdurman, Khartoum state.

Adult Sudanese with sickle cell anemia in the steady state attended haematology clinic during the period from August to November 2017. Total number of patients during that period was thirty. Thirty Medical students of Alneelain University participated as a control group selected matching in physical characteristics to patients group. The study included all adult SCA patient in steady state-Patients free of crises in the last 12 weeks- attending to haematological clinic in military hospital during study period. All patients were homozygous for SCD (SS) as documented by Hemoglobin electrophoreses. Any SCA patients with congenital or acquired heart disease, pregnant women, very severe anemia (hematocrit $<18 \%$ ), known case of renal diseases or on medications other than folic acid and hydroxyurea were excluded from the study.

\section{Methods of data collection}

Interviewed questionnaire was used, which was subdivided into: Background of patients (age, gender, marital status, education level, tribe and residency) and past medical history of sickle cell anemia.

\section{Anthropometric measures}

Weight was measured by electronic scale in kilograms. Participants were standing, heavy clothes were taken off and absolute empty pockets. The weight was approximated by decreasing $0.5 \mathrm{~kg}$ from participant's readings, clothes were considered. Height, waist and hip circumferences were measured by simple tape. Waist circumference was measured three times at the level of umbilicus, between lower margin of the lowest rib and superior surface of iliac crest, the mean value was considered as a reference value. The tape was placed three times around the widest area at hip region to measure hip circumference. Body mass index was calculated using this equation: $\mathrm{BMI}=$ weight $(\mathrm{kg})$ / Height2 (m). Grading of BMI was done according to WHO grading (normal values: $18.5-24.9 \mathrm{~kg} / \mathrm{m} 2$, below 18.5 are underweight, individuals with BMI ranging from 25 to 29.9 are overweight BMI, above 30 are labeled obese and those with BMI more than 35 are morbid obese).

\section{Blood pressure}

Was measured by mercury sphygmomanometer with suitable cuff; covering two thirds of upper arm, applied $2.5 \mathrm{~cm}$ above the cubital fossa, brachial artery was localized well, patients were sitting in comfortable temperature.

\section{Blood samples}

Venous blood sample of $6 \mathrm{ml}$ after $8 \mathrm{~h}$ overnight fasting was drawn, distributed in two tubes one of lithium heparin for clinical chemistry (Lipid profile, uric acid and FBG) done by spectrophotometer, and other of EDTA for cell counting. NCEP ATPIII definition was used to diagnose metabolic syndrome.

Definition of metabolic syndrome according to NCEP - ATP III, if three factors of the followings were achieved [3]:

\begin{tabular}{ll}
\hline Risk factor & Defining level \\
Waist circumference & - Men $>102 \mathrm{~cm}$ \\
& - Women $>89 \mathrm{~cm}$ \\
Blood pressure & - Systolic $\geq 130 \mathrm{mmHg}$ \\
& - Diastolic $\geq 85 \mathrm{mmHg}$ \\
$\mathrm{HDL}$ & $-<40 \mathrm{mg} / \mathrm{dL}$ \\
Triglycerides & $->150 \mathrm{mg} / \mathrm{dL}$ \\
Fasting blood glucose & $->110 \mathrm{mg} / \mathrm{dL}$ \\
\hline
\end{tabular}


Statistical analysis was performed using SPSS software version 23. Continuous data were expressed using mean \pm SD. $P$-value of $<0.05$ (two-tailed) was used to establish statistical significance. Unpaired independent $\mathrm{T}$ - test was used.

\section{Results}

This study was done on thirty patients with $\mathrm{Hb}$ SS and thirty medical students $\mathrm{Hb}$ AA to study the determinants of metabolic syndrome. Table 1 displays the background of both sickle cell anemia patients and controls. Age showed no significant difference between patients and control group $(23.06 \pm 6.06$ vs $20.73 \pm 1.81$ respectively, $p$ value $=0.05$ ). Gender showed no significant difference between two groups.

In Table 2 Body Mass Index (BMI) showed no statistical difference between patients and control group $(20.8 \pm 3.1$ vs $22.10 \pm 4.56$ respectively, $p$ value $=0.2)$. Waist circumference showed non-significant difference between patients group compared to control group ( $\mathrm{p}$ value $=0.15$ ). Hip circumference was significantly lower in patients group compared to control group $(p<0.001)$. Waist-hip ratio was significantly higher among patients group compared to control $(p=0.001)$.

Table 3 displays that the SBP with no significant difference between patients and control groups $(P$ value $=0.31)$. DBP was significantly low in SCD $(65.4 \pm 10.4 \mathrm{mmHg})$ compared to control $(72.33 \pm$ 8.27), $p$ value $>0.001$. PP was not differ in two groups $(40.70 \pm 1.13 \mathrm{mmHg}$ vs $37.23 \pm 9.87 \mathrm{mmHg}$ respectively, $\mathrm{p}$ value $=0.23$. . MAP was lower in patients compared to control $(79 \pm 1.16 \mathrm{mmHg}$ vs $84.30 \pm 7.57 \mathrm{mmHg}$, respectively. $P=0.05$ ).

Table 4 represents the levels of fasting lipid profile in patients and their matched control group. The fasting cholesterol level was not statistically high in patients compared to control group ( $p$ value $=0.17$ ). There was no significant difference in F.TG between patients and control group ( $\mathrm{p}$ value $=0.56$ ). Both HDL and LDL level were significantly lower in patients group compared to control group ( $\mathrm{p}$ value $=0.00, \mathrm{p}$ value $=0.00$ ) respectively. Fig. 1 demonstrates fasting blood glucose level is lower in patients compared to contro. $(P$ value $=0.01)$. Fig. 2 shows no significant difference in serum uric acid among patients and control groups $(6.0 \pm 3.6 \mathrm{mg} / \mathrm{dl}$ vs $5.52 \pm 2.93 \mathrm{mg} / \mathrm{dl}$ respectively, $p$ value $=0.56$ ) .

Table 1 Background characteristics of Participants

\begin{tabular}{lllll}
\hline Characteristics & subjects & & P value \\
\cline { 2 - 4 } & $\begin{array}{l}\text { Sickle patients } \\
(\mathrm{N}=30)\end{array}$ & $\begin{array}{l}\text { Control } \\
(\mathrm{N}=30)\end{array}$ & $\begin{array}{l}\text { Total } \\
(\mathrm{N}=60)\end{array}$ & \\
& $23.06 \pm 6.06$ & $20.73 \pm 1.82$ & $22 \pm 4.59$ & 0.05 \\
\hline AGE IN YEARS & mean $\pm \mathrm{SD})$ & & \\
GENDER: MALES & $13(43.3 \%)$ & $11(36.7 \%)$ & $24(40 \%)$ & 0.23 \\
\hline
\end{tabular}

Table 2 Anthropometric Measurements of Participants

\begin{tabular}{|c|c|c|c|c|}
\hline \multirow[t]{2}{*}{ Characteristics } & \multicolumn{3}{|l|}{ subjects } & \multirow[t]{2}{*}{$P$ value } \\
\hline & $\begin{array}{l}\text { Sickle } \\
\text { patients } \\
(\mathrm{N}=30) \\
(\text { mean } \pm \mathrm{SD})\end{array}$ & $\begin{array}{l}\text { Control } \\
(\mathrm{N}=30) \\
(\text { mean } \pm \mathrm{SD})\end{array}$ & $\begin{array}{l}\text { Total } \\
(\mathrm{N}=60) \\
(\text { mean } \pm \\
\mathrm{SD})\end{array}$ & \\
\hline Body Mass Index & $20.8 \pm 3.1$ & $22.10 \pm 4.56$ & $21.5 \pm 3.67$ & 0.20 \\
\hline $\begin{array}{l}\text { Waist } \\
\text { circumference }(\mathrm{cm})\end{array}$ & $69.77 \pm 7.16$ & $73.30 \pm 11.07$ & $71.53 \pm 9.41$ & 0.15 \\
\hline $\begin{array}{l}\text { Hip circumference } \\
(\mathrm{cm})\end{array}$ & $79.8 \pm 5.13$ & $95.6 \pm 12.29$ & $87.2 \pm 11.90$ & $0.00^{\mathrm{a}}$ \\
\hline Waist - hip ratio & $0.86 \pm 0.49$ & $0.78 \pm 0.11$ & $0.78 \pm 0.1$ & $0.00^{\mathrm{a}}$ \\
\hline
\end{tabular}

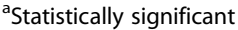

Table 5 shows criteria of metabolic syndrome. There is $3.3 \%$ of females with sickle cell disease have triglycerides level $\geq 150 \mathrm{mg} / \mathrm{dl}$.

About $93.3 \%$ of males and $100 \%$ of females with SCD have HDL level $<40 \mathrm{mg} / \mathrm{dl}$, while $10.3 \%$ of males and $14.6 \%$ of females HbAA have HDL level $<40 \mathrm{mg} / \mathrm{dl}$.

There is $3.3 \%$ of males and $3.3 \%$ of females with SCD have systolic blood pressure $\geq 130 \mathrm{mmHg}$. While $3.3 \%$ of males with SCD have diastolic blood pressure $\geq$ $85 \mathrm{mmHg}$ and $6.7 \%$ of males with SCD have fasting blood glucose level $\geq 110 \mathrm{mg} / \mathrm{dl}$.

Only one patient with SCD has a metabolic syndrome (SBP $=160 \mathrm{mmHg}$, Fasting HDL $=23 \mathrm{mg} / \mathrm{dl}$ and Fasting $\mathrm{TG}=176 \mathrm{mg} / \mathrm{dl}$ ). In contrast to one participant from the control group has a metabolic syndrome (FBS $=120 \mathrm{mg}$ / $\mathrm{dL}, \mathrm{HDL}=32 \mathrm{mg} / \mathrm{dL}$ and $\mathrm{TG}=150 \mathrm{mg} / \mathrm{dL}$ ).

\section{Discussion}

Sudan is one of the most populous countries of sickle cell disease. Some literature investigates the risk factors of metabolic syndrome development among this group of patients [2]. In this study the mean waist circumference in SCA patients was not differ among males and females (Data not shown) which is far away lower to be a risk factor for metabolic syndrome to develop: waist circumference must be $\geq 102 \mathrm{~cm}$ (male), $\geq$ $89 \mathrm{~cm}$ (female) [2]. The mean waist circumference was not significantly differing between patients and control groups. A study done by Uche et al., (2017) on 58

Table 3 Blood Pressure among Participants

\begin{tabular}{lllll}
\hline Variable & $\begin{array}{l}\text { Sickle patients } \\
(\mathrm{N}=30) \\
(\mathrm{mean} \pm \mathrm{SD})\end{array}$ & $\begin{array}{l}\text { Control } \\
(\mathrm{N}=30)\end{array}$ & $\begin{array}{l}\text { Total } \\
(\mathrm{N}=60)\end{array}$ & $P$ value \\
\hline SBP & $106.1 \pm 16.4$ & $109.6 \pm 9.09$ & $107.9 \pm 13.27$ & 0.31 \\
DBP & $65.4 \pm 10.4$ & $72.33 \pm 8.27$ & $68.88 \pm 9.96$ & $0.00^{\mathrm{a}}$ \\
PP & $40.7 \pm 1.13$ & $37.2 \pm 9.8$ & $39.1 \pm 1.1$ & 0.23 \\
MAP & $79 \pm 1.16$ & $84.3 \pm 7.57$ & $81.47 \pm 1.02$ & 0.05
\end{tabular}

${ }^{\mathrm{a}}$ Statistically significant 
Table 4 Fasting Lipid Profile in Participants

\begin{tabular}{lllll}
\hline Biomarker & $\begin{array}{l}\text { Sickle patients } \\
(\mathrm{N}=30) \\
(\mathrm{mean} \pm \mathrm{SD})\end{array}$ & $\begin{array}{l}\text { Control } \\
(\mathrm{N}=30) \\
(\mathrm{mean} \pm \mathrm{SD})\end{array}$ & $\begin{array}{l}\text { Total } \\
(\mathrm{N}=60)\end{array}$ & $P$ value \\
\hline F. Cholesterol & $112.3 \pm 43.89$ & $98.34 \pm 29.96$ & $104.56 \pm 37.10$ & 0.17 \\
F. TG & $82.8 \pm 3.96$ & $91.37 \pm 6.23$ & $87.53 \pm 5.29$ & 0.56 \\
F.HDL & $30.2 \pm 8.15$ & $44.71 \pm 1.85$ & $37.49 \pm 1.59$ & $0.00^{\mathrm{a}}$ \\
F.LDL & $66.37 \pm 4.06$ & $32.32 \pm 2.24$ & $49.12 \pm 3.50$ & $0.00^{\mathrm{a}}$ \\
\hline
\end{tabular}

SD standard deviation, $F$ Fasting, TG Triglyceride, HDL High Density Lipoprotein. LDL Low Density Lipoprotein

${ }^{\text {a }}$ Statistically significant

patients with SCA found no significant difference of mean waist circumference between patients and control group [4]. Their results was confirmed by study performed by Shawn M Bediako et al. (2015) among 49 adult sickle cell patients [2]. The researchers proposed that nearly half of participants in that study were overweight and had dietary saturated fat intake levels that exceeded both the national average and US Dietary Guidelines [2].

Sickle cell anemia patients complain of hyper metabolic state due to increase circulating pro-inflammatory markers (C-reactive protein and plasma interleukins) and increase resting energy expenditure these two factors decreasing the BMI and waist circumference [8].

The mean hip circumference was significantly lower in SCA compared to control as shown in Table 3. Uche et al., (2017) in their study on 58 SCA patients found significant decrease in hip circumference compared to control which is comparable with our results [4]. This lower hip circumference could be attributed to recurrent episodes of avascular necrosis of the femoral head [4].

The first to describe the relationship between sickle cell and blood pressure were Johnson and his colleagues, in 1981 [9]. In our study the brachial systolic blood pressure in SCA patients was not significantly different from that of the controls ( $p$ value $=0.4)$, but the diastolic blood pressure was significantly lower in the patients group compared to controls ( $\mathrm{p}$ value $<0.05$ ), and the MAP was also found to be significantly lower in patients group compared to control ( $\mathrm{p}$ value $<0.05$ ).

Several studies conducted among sickle patients showed low blood pressures compared to control group [8-11]. Another study done in neighbour country Kenya- by Ayuo et al., (1993) reported comparable findings to ours, in which the systolic blood pressure found to be comparable with that of the controls, while the diastolic blood pressure was significantly lower than that of the controls [12]. The mean blood pressure among SCA patients in current study was (106/ $65 \mathrm{mmHg}$ ), which is far away lower to be a risk factor for metabolic syndrome; which is by definition must be $\geq 130 / 85 \mathrm{mmHg}$ [3]. In our study $3.3 \%$ of males and 3.3\% of females with SCA have systolic blood pressure $\geq$ $130 \mathrm{mmHg}$, while $3.3 \%$ of males have diastolic blood pressure $\geq 85 \mathrm{mmHg}$ and they could be consider as risk groups. Recent studies found that SCA patients may develop low blood pressures due to hypoxia of the chronic anaemic state; the hypoxia causes vasodilatation leading to lower peripheral resistance and reducing systemic blood pressure [10]. In conclusion, our findings

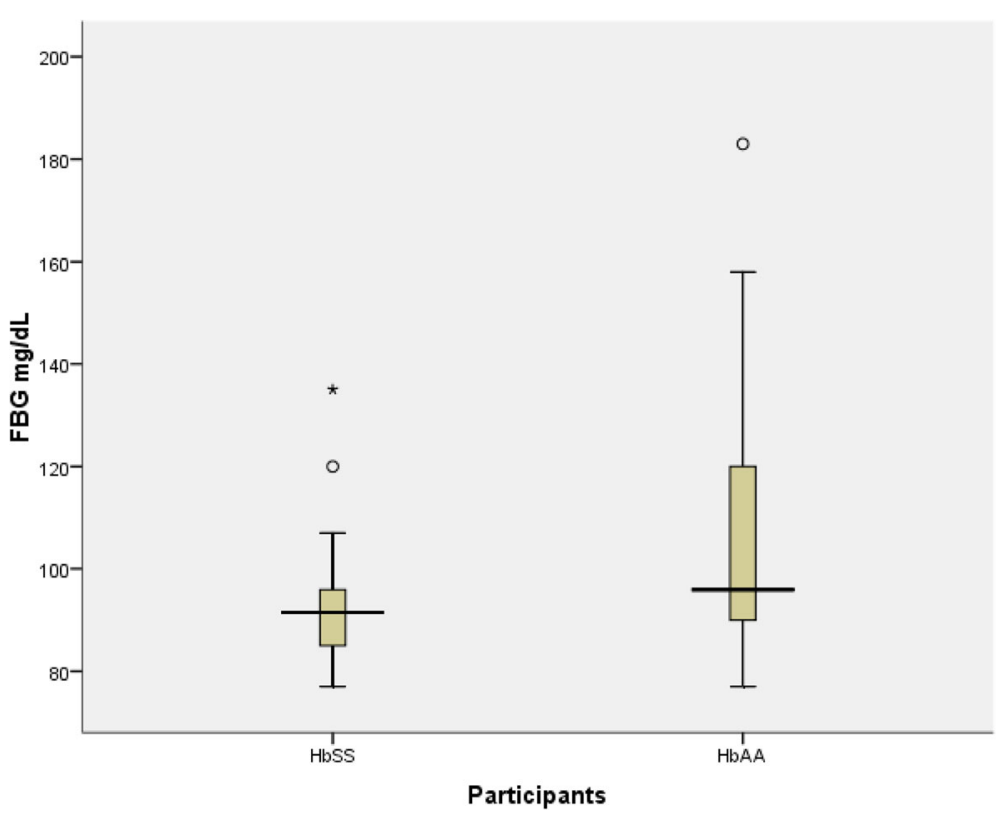

Fig. 1 Fasting Blood Glucose in Sickle Cell Disease Patients Compared to Control 


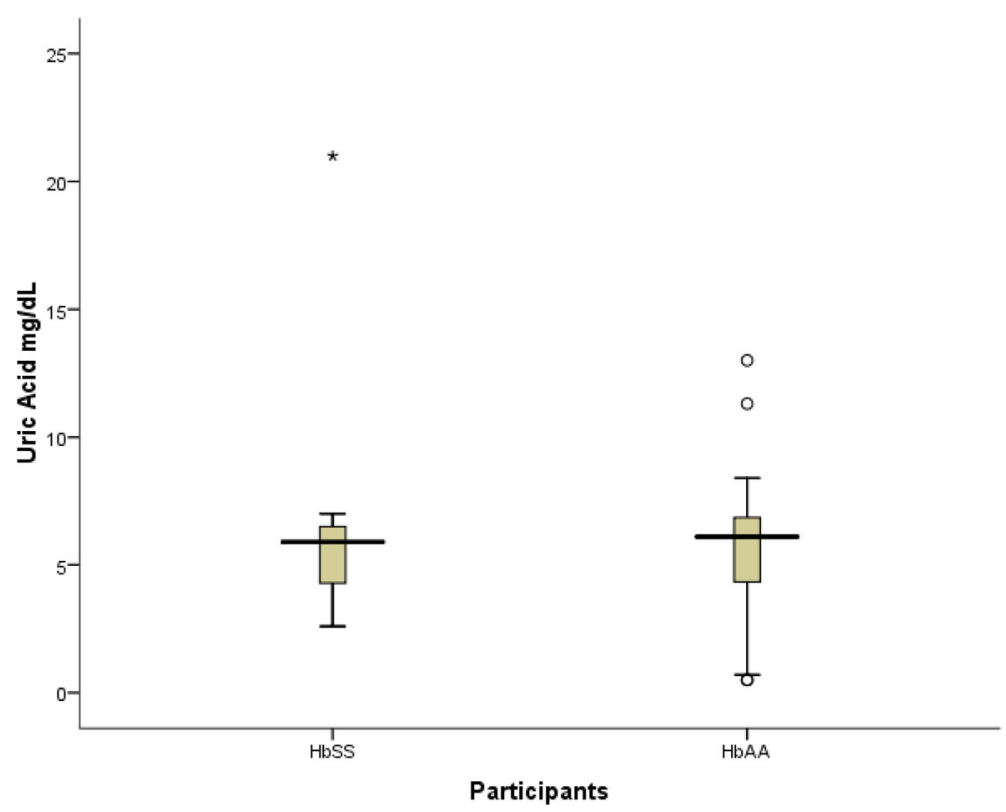

Fig. 2 Uric Acid Level in Sickle Cell Disease Patients Compared to Control

support previous studies of relatively lower arterial blood pressure in patients with SCA.

Nowadays some studies investigated the effect of SCA on patient's lipid profile. In our study, fasting cholesterol level was not significantly higher in patients group compared to control group. Fasting triglycerides was not significantly low in patients group compared to the control group. F.HDL was significantly lower in patients compared to control group.

Padaro et al.,(2016) found significant decrease in cholesterol and HDL levels in Hb SS patients compared to their controls $[13,14]$. The researchers also found no significant difference in TG between patients and control groups $[15,16]$.

Some literatures investigate the derangement of haemoglobin level with erythropoietin production among SCA patients, which is the main factor for cholesterol utilization for red cells membrane formation [14]. In current study, there is insignificant increase in cholesterol level among SCA, which is incomparable with recent studies; we assumed that this difference in our results could be due to derangements of haemoglobin level with erythropoietin production in these patients.

One of the criteria to diagnose metabolic syndrome is dyslipidaemia: $\mathrm{TG} \geq 150 \mathrm{mg} / \mathrm{dl}$ or $\mathrm{HDL}<40 \mathrm{mg} / \mathrm{dl}$ (male), <50 mg/dl (female) [3]. In our study, the mean TG level was $77.3 \mathrm{mg} / \mathrm{dl}$, which is low to be a risk factor for metabolic syndrome. The mean HDL level was $33.3 \mathrm{mg} / \mathrm{dl}$ (men), $27.82 \mathrm{mg} / \mathrm{dl}$ (women), which it could be consider as a risk factor for metabolic syndrome. Only $6.7 \%$ of males have HDL level $\geq 40 \mathrm{mg} / \mathrm{dl}$.
In this study we found that the mean fasting blood glucose level was significantly lower in patients group in comparison to control as shown in Fig. 1.

A study done on 45 sickle cell patients by Yavropoulou,M.P et al.,(2016) found no significant changes in FBG between patients and control groups [17]. Another study done by A.I.Alsultan et al.,(2010) found significant higher FBG in patients compared to control [5]. The researchers assumed that increase fasting blood glucose level occurs as a consequence of insulin resistance develops among SCA patients [5]. Insulin resistance is defined as an organ failure to respond to insulin and consequently increases circulating blood glucose [5]. Sickled haemoglobin is associated with over-production of reactive oxygen species (ROS) [5]. ROS may interfere with

Table 5 Criteria of Metabolic Syndrome among Sickle Cell Disease and control group According to National Cholesterol Education Program-Adult Treatment Panel III

\begin{tabular}{lllll}
\hline & \multicolumn{2}{l}{$\begin{array}{l}\text { Proportion at } \\
\text { Risk-control* }\end{array}$} & \multicolumn{2}{l}{$\begin{array}{l}\text { Proportion at } \\
\text { Risk-patients* }\end{array}$} \\
\hline & $\begin{array}{l}\text { Male } \\
(n=13)\end{array}$ & $\begin{array}{l}\text { Female } \\
(n=17)\end{array}$ & $\begin{array}{l}\text { Male } \\
(\mathrm{n}=13)\end{array}$ & $\begin{array}{l}\text { Female } \\
(\mathrm{n}=17)\end{array}$ \\
Waist circumference (cm) & $0.0 \%$ & $0.0 \%$ & $0.0 \%$ & $0.0 \%$ \\
Triglycerides (mg/dl) & $0.0 \%$ & $7.3 \%$ & $0.0 \%$ & $3.3 \%$ \\
HDL (mg/dl) & 10.3 & 14.6 & $93.3 \% *$ & $100 \%^{*}$ \\
Systolic BP mmHg & $0.0 \%$ & $0.0 \%$ & $3.3 \%$ & $3.3 \%$ \\
Diastolic BP mmHg & $0.0 \%$ & $0.0^{*}$ & $3.3 \%$ & $0.0 \%$ \\
Fasting Glucose (mg/dl) & $15.4 \%$ & $19.3 \%$ & $6.7 \%$ & $0.0 \%$ \\
Metabolic Syndrome & $0.0 \%$ & $3.3 \%$ & $0.0 \%$ & $3.3 \%$ \\
\hline
\end{tabular}


insulin signalling at various levels, impairing insulin uptake through a direct effect on insulin receptor function [18]. ROS may reduce glucose uptake by inhibiting the translocation of GLUT4 (glucose transporter 4) to the plasma membrane leading to increase serum blood glucose level [19]. One of the criteria to diagnose metabolic syndrome is fasting plasma glucose $\geq 110 \mathrm{mg} / \mathrm{dl}$ [20].

In this study, only $6.7 \%$ of adult male patients have FBG level $\geq 110 \mathrm{mg} / \mathrm{dl}$, Table 5 . They may consider as a group of risk of metabolic syndrome.

Secondary gout is a well-recognised complication of increased nucleic acid catabolism in red cells turnover among SCA [21]. In this study we found the mean serum uric acid level was insignificantly differ between $\mathrm{Hb}$ SS patients and control group. Only $13.3 \%$ of patients have uric acid level greater than $6.8 \mathrm{mg} / \mathrm{dl}$. Previous studies done in Iraq and Brazil found no significant difference in uric acid level between sickle cell patients and their matched control [20,21].

Sickle cell anaemia nowadays categorized as syndrome rather than a disease. It affects many organs and can be consider as a life threatening condition. These patients may die younger than other population may be due to complications of the disease. This study added new insight to focus on metabolic syndrome development among SCD patients as a complication of the disease. And my shift focus to new therapy strategies to improve patients' quality of life and reduce both mortality and morbidity.

\section{Conclusions}

There was significant decrease in HDL,DBP, and hip circumference values among SCD patients with no significant difference in cholesterol, triglycerides, SBP, and MAP waist circumference values among SCA patients compared to control.

\section{Acknowledgements}

The authors would like to thank participants at Al-Neelain University for their kind help and cooperation during the study. And Thank Dr. Alnazeer Mohammed and Dr.Mohamed Abdelazim Osman for their kind help in data collection.

\section{Funding}

Fund was obtained from Alnnelain University to AS.

\section{Availability of data and materials}

The datasets used and/or analysed during the current study are available from the corresponding author on reasonable request.

\section{Authors contributions}

$A B$, and $L K$ participated in study design. $A B$ and $L K$ were involved in all aspects of the study conduct. AB collected data. AB and LK analysed data. LK and $A B$ participated in the writing and review of the manuscript. All authors approved final version of manuscript.

\section{Ethics approval and consent to participate}

The study was approved by the Central Institutional Review Board at Al -Neelain University. Also, written informed consent was obtained from each participant prior to enrolment.

\section{Consent for publication}

Principal investigator obtained informed consent from each participant to publish the data without breaching confidentiality.

\section{Competing interests}

We declare no conflict of interest.

\section{Publisher's Note}

Springer Nature remains neutral with regard to jurisdictional claims in published maps and institutional affiliations.

Received: 8 February 2018 Accepted: 25 June 2018

Published online: 27 December 2018

\section{References}

1. Zorca S, Freeman L, Hildesheim M, Allen D, Remaley AT, Taylor JG, et al. Lipid levels in sickle-cell disease associated with haemolytic severity, vascular dysfunction and pulmonary hypertension. $\mathrm{Br} J$ Haematol [lnternet]. 2010;149(3):436-445.

2. Bediako SM, Nelson J, Cichowitz C, YU T, Carroll CP, Stewart KJ, et al. Metabolic Syndrome Risk Among Adults Living with Sickle Cell Disease. Blood [lnternet]. 2015;126(23).

3. Grundy SM, Cleeman JI, Daniels SR, Donato KA, Eckel RH, Franklin BA, Gordon DJ, Krauss RM, Savage PJ, Smith SC, et al. Diagnosis and management of the metabolic syndrome: an American Heart Association/ National Heart, Lung, and Blood Institute scientific statement. Circulation. 2005;112:2735-52. https://doi.org/10.1161/CIRCULATIONAHA.105.169404.

4. Uche A, et al. Correlates of Steady State Lipid Profile and Anthropometric Parameters in Adult Sickle Cell Anaemia Patients in South-West Nigeria. IOSR J Dent Med Sci [Internet]. 2017;16(2):76-81.

5. Alsultan Al, Seif MA, Amin TT, Naboli M, Alsuliman AM. Relationship between oxidative stress, ferritin and insulin resistance in sickle cell disease. Eur Rev Med Pharmacol Sci [Internet]. 2010;14(6):527-538.

6. Oguanobi NI, Onwubere BJC, Ibegbulam OG, Ike SO, Anisiuba BC, Ejim EC, et al. Arterial blood pressure in adult Nigerians with sickle cell anemia. J Cardiol [Internet]. 2010:56(3):326-331.

7. Reynolds MD. Gout and hyperuricemia associated with sickle-cell anemia. Semin Arthritis Rheum [Internet]. 1983;12(4):404-13.

8. Hibbert JM, Hsu LL, Bhathena SJ, Irune I, Sarfo B, Creary MS, et al, Proinflammatory cytokines and the hypermetabolism of children with sickle cell disease. Exp Biol Med (Maywood) [Internet]. 2005;230(1):68-74.

9. Pikilidou M, Yavropoulou M, Antoniou M, Papakonstantinou E, Pantelidou D, Chalkia P, et al. Arterial stiffness and peripheral and central blood pressure in patients with sickle cell disease. J Clin Hypertens [Internet]. 2015;17(9): 726-731.

10. Pegelow CH, Colangelo L, Steinberg M, Wright EC, Smith J, Phillips G, et al. Natural history of blood pressure in sickle cell disease: risks for stroke and death associated with relative hypertension in sickle cell anemia. Am J Med [Internet]. 1997;102(2):171-177.

11. Gladwin MT, Sachdev V. Cardiovascular abnormalities in sickle cell disease. J Am Coll Cardiol [Internet]. 2012;59(13):1123-1133.

12. Ayuo PO, Abinya NA, Joshi MD, Lore W. Cardiovascular features in adolescents and adults with sickle cell anaemia. East Afr Med J. 1993;70(5): $270-276$.

13. Yavropoulou MP, Pikilidou M, Pantelidou D, Tsalikakis DG, Mousiolis A, Chalkia P, et al. Insulin secretion and resistance in Normoglycemic patients with sickle cell disease. Hemoglobin [Internet]. 2017;41(1):6-11.

14. Henriksen EJ, Diamond-Stanic MK, Marchionne EM. Oxidative stress and the etiology of insulin resistance and type 2 diabetes. Free Radic Biol Med [Internet]. 2011;51(5):993-999.

15. Essohana P, Irenee K, Delagnon M, Lochina F, Hezouwe M, Koffi M, et al. Cholesterol and Triglyceride Levels in Patients with Homozygous Sickle Cell Disease at Campus Teaching Hospital of Lomé (Togo). Sci I Clin Med [Internet]. 2016;5(2):24-8.

16. Ephraim RKD, Adu P, Ake E, Agbodzakey H, Adoba P, Cudjoe O, et al. Normal Non-HDL Cholesterol, Low Total Cholesterol, and HDL Cholesterol Levels in Sickle Cell Disease Patients in the Steady State: A Case-Control Study of Tema Metropolis. J Lipids [Internet]. 2016;2016:1-5.

17. Garvey WT, Maianu L, Zhu JH, Brechtel-Hook G, Wallace P, Baron AD. Evidence for defects in the trafficking and translocation of GLUT4 glucose 
transporters in skeletal muscle as a cause of human insulin resistance. J Clin Invest [Internet]. 1998;101(11):2377-2386.

18. Wt G, Maianu L, Zhu J-H, Brechtel-Hook G, Wallace P, Baron AD. Evidence for defects in the trafficking and translocation of GLUT 4 glucose

transporters in skeletal muscle as a cause of human insulin resistance. J Clin Invest. 1998;101:2377-86.

19. Rothschild BM, Sienknecht CW, Kaplan SB, Spindler JS. Sickle cell disease associated with uric acid deposition disease. Ann Rheum Dis [Internet]. 1980;39(4):392-395.

20. Al-Naama LM, al-Sadoon EA, al-Sadoon TA. Levels of uric acid, urea and creatinine in Iragi children with sickle cell disease. J Pak Med Assoc [Internet]. 2000;50(3):98-102.

21. Cerqueira BAV, Boas W V., Zanette AD, Reis MG, Goncalves MS. Increased concentrations of IL-18 and uric acid in sickle cell anemia: contribution of hemolysis, endothelial activation and the inflammasome. Cytokine [Internet]. 2011;56(2):471-476.

Ready to submit your research? Choose BMC and benefit from:

- fast, convenient online submission

- thorough peer review by experienced researchers in your field

- rapid publication on acceptance

- support for research data, including large and complex data types

- gold Open Access which fosters wider collaboration and increased citations

- maximum visibility for your research: over $100 \mathrm{M}$ website views per year

At BMC, research is always in progress.

Learn more biomedcentral.com/submissions 